\title{
Estimation Of Mangaan Carrier Rock Volume Using Geoelectric Method In Empol Sub-Village, West Lombok Regency
}

\author{
${ }^{1}$ Dieni Haryati Utami, ${ }^{2}$ Alfina Taurida Alaydrus, ${ }^{3 *}$ Suhayat Minardi \\ ${ }^{1}$ Physics Department, Faculty of Mathematics and Natural Sciences, University of Mataram, \\ J1. Majapahit No. 62 Mataram, 83125 Indonesia \\ ${ }^{2,3}$ Geophysics Research Group, Faculty of Mathematics and Natural Sciences, University of \\ Mataram, J1. Majapahit No. 62 Mataram, 83125 Indonesia \\ Corresponding author: suhayat.minardi@unram.ac.id
}

\begin{tabular}{|c|c|}
\hline Article Info & Abstract \\
\hline $\begin{array}{l}\text { Article History } \\
\text { Received: November } 2020 \\
\text { Revised: December } 2020 \\
\text { Published: December } 2020\end{array}$ & \multirow{2}{*}{$\begin{array}{l}\text { The research has been done using geoelectric resistivity method to estimate the } \\
\text { volume of Manganese (Mn) carrier rock in Empol sub-village, Central } \\
\text { Sekotong Village, West Lombok NTB. Measurements was conducted with the } \\
\text { Wenner configuration using a Resistivity Meter G-Sound GL-4100. Data was } \\
\text { modeled and calculated using three software, there are Res2Dinv 3.5, Surfer 10, } \\
\text { and Rockwork 15. The rocks that regarded as carrier mangaan is pyrolusite } \\
\text { manganese (Mn02). The description and distribution of MnO2 can be } \\
\text { determined from the results of 2-dimension modeling using Res } 2 \text { Dinv. MnO2 } \\
\text { was detected in almost all resistivity line with value around 0,023 } \Omega \mathrm{m} \text { up to } 9,8 \\
\Omega m \text {. From the 3-dimension visualization processed using RockWorks } 15 \\
\text { software, we obtained volume of pirolusitabout } 38,199 \mathrm{~m}^{3} \text { of area } 160,000 \mathrm{~m}^{2} \text { and } \\
100 \text { m of thickness. }\end{array}$} \\
\hline $\begin{array}{l}\text { Keywords } \\
\text { manganese, pyrolu. } \\
\text { resistivity, volume }\end{array}$ & \\
\hline Informasi Artikel & Abstrak \\
\hline $\begin{array}{l}\text { Sejarah Artikel } \\
\text { Diterima: November } 2020 \\
\text { Direvisi: Desember } 2020 \\
\text { Dipublikasi: Desember } 2020\end{array}$ & \multirow{2}{*}{$\begin{array}{l}\text { Telah dilakukan survey dengan metode geolistrik untuk mengestimasi volume } \\
\text { batuan pembawa mineral Mangaan di Dusun Empol, Desa Sekotong Tengah, } \\
\text { Kabupaten Lombok Barat.. Pengukuran data geolistrik dilakukan dengan } \\
\text { konfigurasi wenner menggunakan Resistivitymeter G-Sound GL-4100. Data } \\
\text { dimodelkan dengan perangkat lunak Res } 2 \text { Dinv } 3.5 \text {, Surfer } 10 \text {, dan Rockwork } \\
\text { 15. Deskripsi dan distribusi MnO2 (pirolusit) diperoleh sebagai hasil } \\
\text { pemodelan } 2 \text { dimensi dengan Res } 2 \text { Dinv. MnO2 dijumpai hampir di semua } \\
\text { lintasan pengukuran geolistrik dengan resistivitas } 0,023 \Omega \text { hingga } 9,8 \Omega \mathrm{m} \text {. } \\
\text { Berdasar visualisi } 3 \text { dimensi denga perangkat lunak Rockwork } 15 \text { diperoleh } \\
\text { volume pirolusit sekitar } 38.199 \mathrm{~m} 3 \text { pada area seluas } 160.000 \mathrm{~m} 2 \text { dan ketebalan } \\
100 \mathrm{~m} \text {. }\end{array}$} \\
\hline & \\
\hline
\end{tabular}

Sitasi: Utami, D.H., Alaydrus, A.T., \& Minardi, S. (2020). Estimation Of Mangaan Carrier Rock Volume Using Geoelectric Method In Empol Sub-Village, West Lombok Regency. Kappa Journal, 4(3), 178-187.

\section{INTRODUCTION}

Based on data from the Ministry of Energy and Mineral Resources of Lombok Island, the geologically Lombok Island are composed of alluvium deposits, inseparable volcanic rocks, tuffs, pumice, breccia and lava, limestone, sandstone and igneous rock (ESDM, 2013). These rocks were store mineral resource contents that can be utilized as mineral commodities such as metal minerals with high economic value, there are also non-metallic minerals such as limestone which are beneficial in the industrial world. One such element that has a high economic value is Manganese (Mn). The most common $\mathrm{Mn}$ metal is pyrrolusite $\left(\mathrm{MnO}_{2}\right)$. In its naturally state, Mn metal is hard but brittle (easily broken), has a high conductivity and a low resistivity value. Mn metal has an iron gray color with metallic to submetallic luster. Most of the Mn metals are often found around garnping stones or very 
hard rocky rubble. The Mn forms a pathway between limestone or limestone deposits. Mn metal outcrops can be seen on hillsides and river banks (Soeharto, 2000).

$\mathrm{Mn}$ is rarely found as a free element in its basic properties and is often mixed with iron and other metals. As one of the important metals, $\mathrm{Mn}$ is widely used as an industrial metal alloy, especially in the stainless steel industry. In addition as a mixture of steel, $\mathrm{Mn}$ is also widely used for a mixture of aluminum, dry battery industry, in pernbuatan ceramics, glassware, as material for welding rod, zinc electrolysis and oxidizing agents in uranium production and so on (Wirayuda, 2013).

Based on the Department of Mining and Energy of the NTB Province data in 2013, the potency of Mn metal in NTB Province is in Desa Sekotong Tengah which is measured around 2.51 million tons. With the abundant potential and the many benefits obtained from the production of Mn, making a lot of $\mathrm{Mn}$ metal explored. However, due to lack of knowledge and information from the local community, the exploration of Mn was not carried out optimally. Therefore an investigation is needed to find out information about the potential of the Mn.

Identification of the Mn potency can be done by several geophysical methods, such as the geoelectric method, the geomagnetic method, the gravity method and the seismic method. Because of the nature of this metal Mn has excellent electrical conductivity and has a low electrical resistivity value, so it is very suitable to be identified using the geoelectric method. This geoelectric method utilizes the electrical properties of rocks or metals and provides information on variations in the resistivity values of each rock or metal. This research will be conducted using the resistivity geoelectric method with the Wenner configuration. The advantage of this Wenner configuration is the accuracy of the voltage reading at the potential electrode.

Manganese (Mn) is an active chemical metal in metallic luster gray iron. Mn is the twelve most abundant elements in the earth's crust has atomic number 25 which has a high melting point of around $1519^{\circ} \mathrm{C}$, while the boiling point of $\mathrm{Mn}$ there at a temperature of $2061^{\circ} \mathrm{C}$ with a density of $7.21 \mathrm{gr} / \mathrm{cm}^{3}$. Under normal states it has a solid form and hard but very fragile, hard to melt but easily oxidized. Metals and Mn ions are paramagnetic. Mn is often found in forms sediment ore deposits, generally composed of oxides as well as being associated with volcanic activities and basic rocks. Mn ore compounds are found in the form of pyrrolusite rock $\left(\mathrm{MnO}_{2}\right)$ psilomelan $\left(\mathrm{Ba}, \mathrm{H}_{2} \mathrm{O}\right)$, and sometimes also found hodocrocytes $\left(\mathrm{MnC}_{3}\right)$. The largest source of $\mathrm{Mn}$ is found at nature is in the form of pyrroleusite rocks. Rock The pyrrolusite has an iron gray color sometimes it can also be reddish gray as shown in Figure 1 (Wirayuda, 2013).

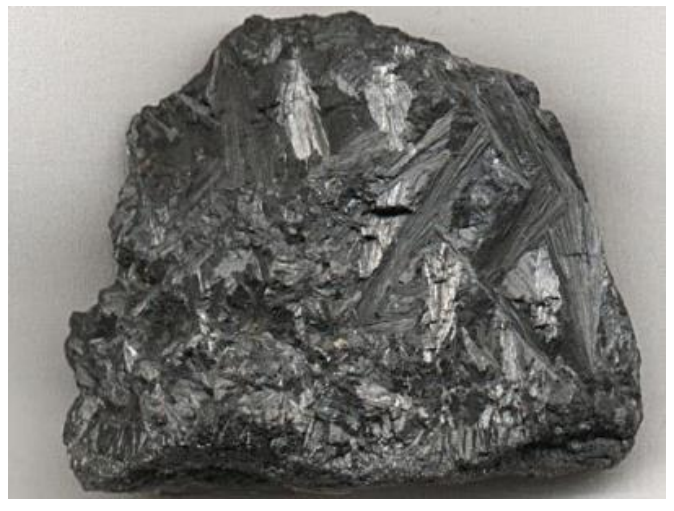

Figure 1 Rocks containing Mn (pyrrolusite) (http://pangestu.blogspot.co.id)

Based on the value of the electrical resistivity, rock and minerals can be grouped into three, i.e: (Telford et al., 1990).

a. Good conduct: $10^{-8}<\rho<1 \Omega \mathrm{m}$

b. Mid conductor: $1<\rho<10^{7} \Omega \mathrm{m}$

c. insulator: $\rho>10^{7} \Omega \mathrm{m}$ 
Based on the above division, rocks Pyrrolusite is included in the conductor because it is good has a resistivity value of about $5 \times 10^{-3} \Omega \mathrm{m}$ to $10 \Omega \mathrm{m}$. Value of several rock material shown in Table 1 .

Table 1. Resistivity of several rock materials (Telford et. al., 1990)

\begin{tabular}{lc}
\hline Material & Resistivity $(\Omega \mathrm{m})$ \\
\hline Pyrite & $3 \times 10^{-1}$ \\
Bauxite & $2 \times 10^{2}-6 \times 10^{3}$ \\
Pyrrolusite & $5 \times 10^{-3}-10$ \\
Granite & $10^{2}-10^{6}$ \\
Galena & $10^{-3}-10^{3}$ \\
Andesite & $10^{2}-10^{3}$ \\
Basalt & $10-10^{7}$ \\
\hline
\end{tabular}

\begin{tabular}{lc}
\hline Material & Resistivity $(\Omega \mathrm{m})$ \\
\hline Iron ore & $3.5 \times 10^{-3}-10^{2}$ \\
Mica & $2 \times 10^{12}-10^{14}$ \\
Tuff & $2 \times 10^{1}-10^{2}$ \\
Clay & $10^{2}$ \\
Breccia & $7.5 \times 10^{1}-2 \times 10^{2}$ \\
Sandstone & $1-6 \times 10^{8}$ \\
Limestone & $5 \times 10-10^{7}$ \\
\hline
\end{tabular}

\subsection{Geoelectrical Method}

The geoelectric method is one geophysical methods that study the nature of flow electricity in the earth and how detect it on the surface of the earth. In terms of this includes potential measurements and measurements currents, both naturally and as a result of injection currents into the earth. Therefore the geoelectric method has many kinds, including the self-potential method, megnetotelluric, electromagnetic, induced polarization (IP) and resistivity (Reynold, 1997).

The resistivity geoelectric method is one of the most methods commonly used in geoelectric exploration. This method is used to describe subsurface by studying the electrical resistivity of the rock layers in the earth, where the earth is composed of rocks that have different electrical conductivity (Karisma, 2013). Geoelectric investigation by method resistivity is based on Ohm's Law, which states that it is potential different due to a load is directly proportional with electric current. The relationship between magnitude electric potential difference $(\Delta \mathrm{V})$, electric current strength (I), and the magnitude of the resistance of conductor $(\mathrm{R})$ is expressed in equation (1) (Wahyuni, 2011).

$$
\Delta V=I R
$$

If the conductor is in the form of a cylinder made of homogeneous material with the length (L) and cross-sectional area (A), as shown in Figure 2, the electric current (I) will flow in the direction parallel to the $(\mathrm{L})$, so that the comparison between the measured potential difference and the electric current is a function cylinder dimensions. Mathematically can be written as:

$$
R=\rho \frac{L}{A}
$$

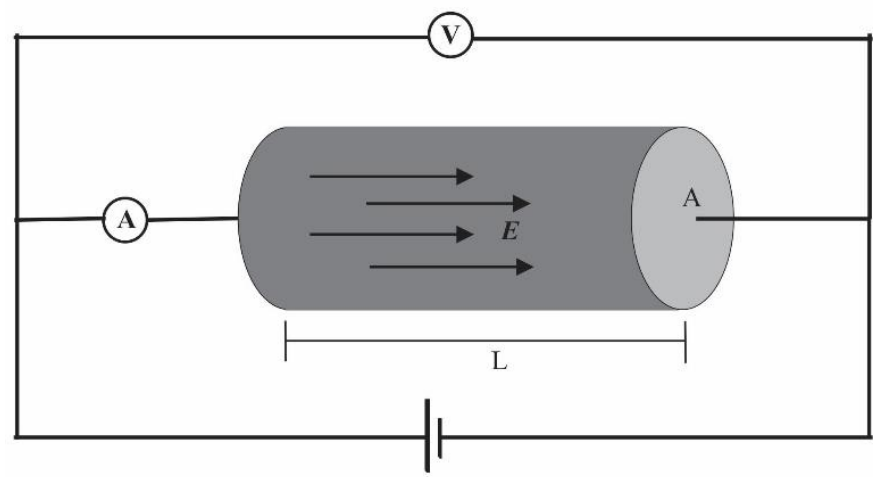

Figure 2 Current flow on cylinder conductor (modified from Margaworo, 2009) 
Equations (1) and (2) only acceptable with the assumption that the medium of conductor has the same current density (homogeneous), so that along the conductor there is no potential change. In reality in the field will flow current into the ground which generally has a varying current density and in flowing current, will move the current and potential electrodes. With a different density, then the resistivity value will change, so that:

$$
\rho=\frac{\Delta V}{I} \frac{A}{L}
$$

The earth is assumed to be an isotropic homogeneous medium. Suppose the current electrode flows the current in an isotropic medium, a half-sphere equipotential plane is $2 \pi r^{2}$. When an electric current is flowed into the earth, electric current will flow in all directions and form a half-ball as shown in Figure 3, so that the value of the potential difference is measured as (Telford et al., 1976).

$$
\rho=2 \pi r \frac{\Delta V}{I}
$$

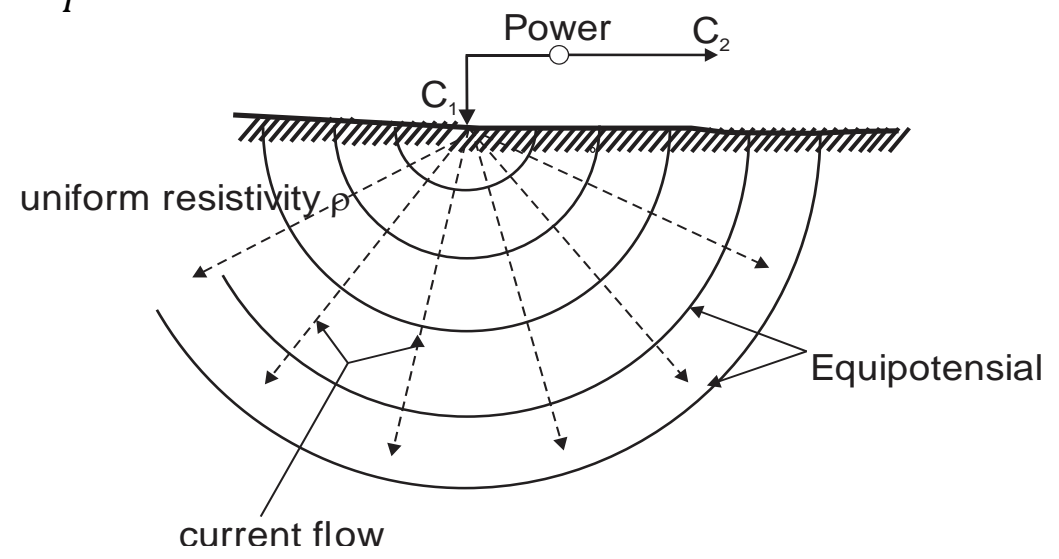

Figure 3 Current source point on the surface isotropic homogeneous (modified from

Telford et al., 1990).

In this study two electrodes were used to conduct current $\left(\mathrm{C}_{1}\right.$ and $\left.\mathrm{C}_{2}\right)$ and their potential difference was measured between two points using two potential electrodes $\left(\mathrm{P}_{1}\right.$ and $\left.\mathrm{P}_{2}\right)$. If the distance $(\mathrm{r})$ between two current electrodes is made with a certain distance Figure 4, the potential near the surface will be influenced by the two current electrodes, then the potential at point $\mathrm{P}_{1}$ is (Telford et al., 1990):

$$
\Delta V_{1}=\rho \frac{I}{2 \pi}\left(\frac{1}{r_{1}}-\frac{1}{r_{2}}\right)
$$

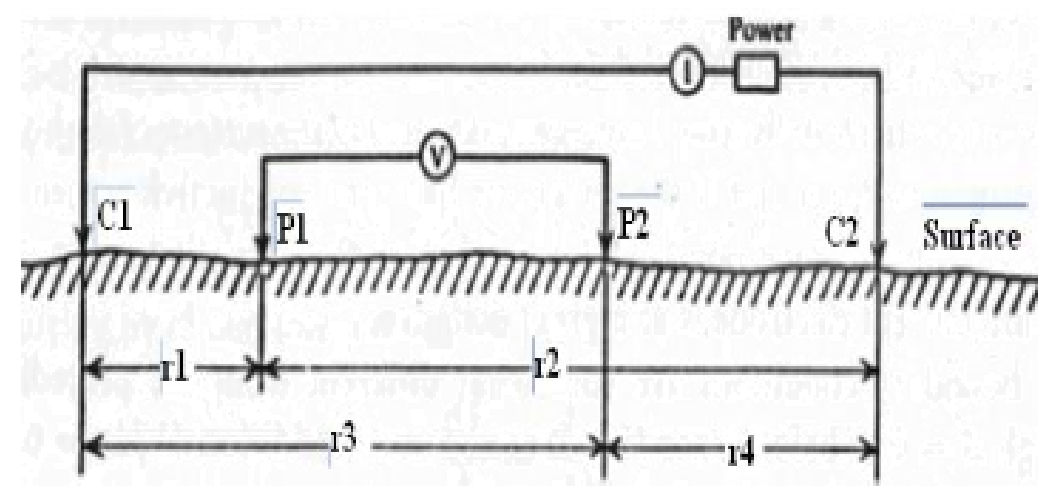

Figure 4 Two current electrodes and two potential electrodes on resistivity measurement (modified from Telford et al., 1990). 
And potential at electrode $\mathrm{P}_{2}$ is:

$$
\Delta V_{2}=\rho \frac{I}{2 \pi}\left(\frac{1}{r_{3}}-\frac{1}{r_{4}}\right)
$$

Potential difference among electrode $\mathrm{P}_{1}$ and $\mathrm{P}_{2}$ is:

$$
\Delta V=\rho \frac{I}{2 \pi}\left[\left(\frac{1}{r_{1}}-\frac{1}{r_{2}}\right)-\left(\frac{1}{r_{3}}-\frac{1}{r_{4}}\right)\right]
$$

In actual conditions, the earth consists of layers of soil with different $\mathrm{p}$ values. The measured potential is the potential field value by the layered medium. Thus the measured resistivity on the surface of the earth is not the actual resistivity value but apparent resistivity. Based on equation (7), it is obtained

$$
\rho_{a}=2 \pi\left[\left(\frac{1}{r_{1}}-\frac{1}{r_{2}}\right)-\left(\frac{1}{r_{3}}-\frac{1}{r_{4}}\right)\right]^{-1} \frac{\Delta V}{I}
$$

By substituting the equation (8) with equation (9) it will obtain the value of $\mathrm{K}$ as

$$
\rho_{a}=K \frac{\Delta V}{I}
$$

So that the apparent resistivity is formulated as:

$$
K=2 \pi\left[\left(\frac{1}{r_{1}}-\frac{1}{r_{2}}\right)-\left(\frac{1}{r_{3}}-\frac{1}{r_{4}}\right)\right]^{-1} \text { meter }
$$

The wenner configuration is one of the electrode configurations in the geoelectrical resistivity method which uses four electrodes consisting of two current electrodes $\left(\mathrm{C}_{1}\right.$ and $\left.\mathrm{C}_{2}\right)$ and two potential electrodes $\left(\mathrm{P}_{1}\right.$ and $\left.\mathrm{P}_{2}\right)$ with the distance between each electrode being made equal (value a $\left.=\mathrm{C}_{1} \mathrm{P}_{1}=\mathrm{P}_{1} \mathrm{P}_{2}=\mathrm{P}_{2} \mathrm{C}_{2}\right)$. The advantage of this Wenner configuration is that the accuracy of the voltage reading at the $\mathrm{P} 1 \mathrm{P} 2$ electrode is better with a relatively large number because the $\mathrm{P}_{1} \mathrm{P}_{2}$ electrode is relatively close to the $\mathrm{C}_{1} \mathrm{C}_{2}$ electrode. In the Wenner configuration multimeter measuring devices with relatively smaller impedances can be used. While its weakness is that it cannot detect the homogeneity of rocks near the surface which can affect the results of calculations. The data obtained from the measurement of the Wenner configuration, is very difficult to eliminate the rock non-homogeneity factor, so the calculation results are less accurate. The configuration of the Wenner electrode is shown in Figure 5 below.

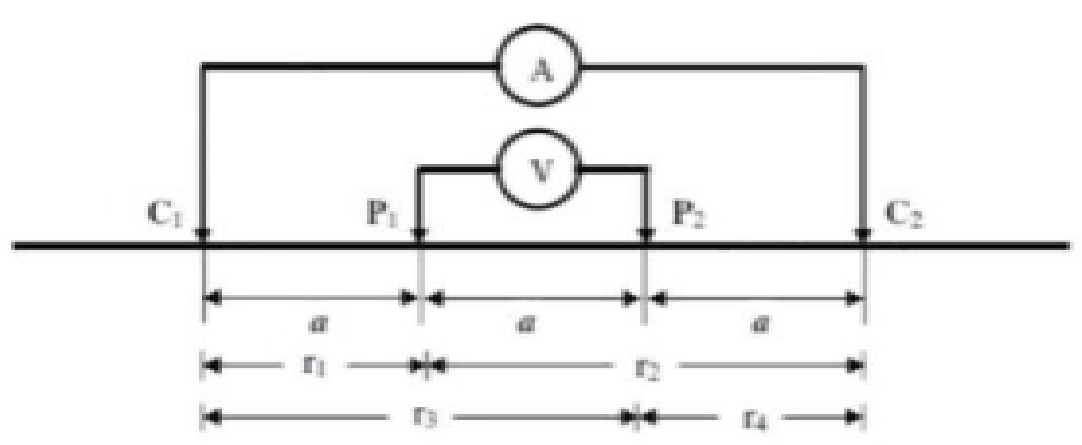

Figure 5 Schematic of electrodes in Wenner configuration resistivity (Reynold, 1997). 
Based on equation (8) and Figure 5, with spaces a where $r,=r_{3}=a$ and $r_{2}=r_{4}=2 a$, so we get the geometry factor $(\mathrm{K})$ value for the Wenner configuration is

$$
K=2 \pi a \text { meter }
$$

Then the apparent resistivity $\left(\rho_{\mathrm{a}}\right)$ value is obtained

$$
\rho_{a}=2 \pi a \frac{\Delta V}{I}
$$

This research area is located $25 \mathrm{~km}$ from Mataram, precisely located in Empol sub-village, Central Sekotong Village, Sekotong sub-district, West Lombok Regency, West Nusa Tenggara Province. The Sekotong region is generally an area formed by volcanoes which are generally the oldest tertiary rocks as shown in Figure 6. The oldest rocks are Tertiary and the youngest are Quaternary dominated by Volcanic Rock and Aluvium (resent). Tertiary rocks on Lombok Island consist of interlocking quartz sandstone, claystone, breccias, lava, tuff with limestone lenses (Gunradi, 2005).

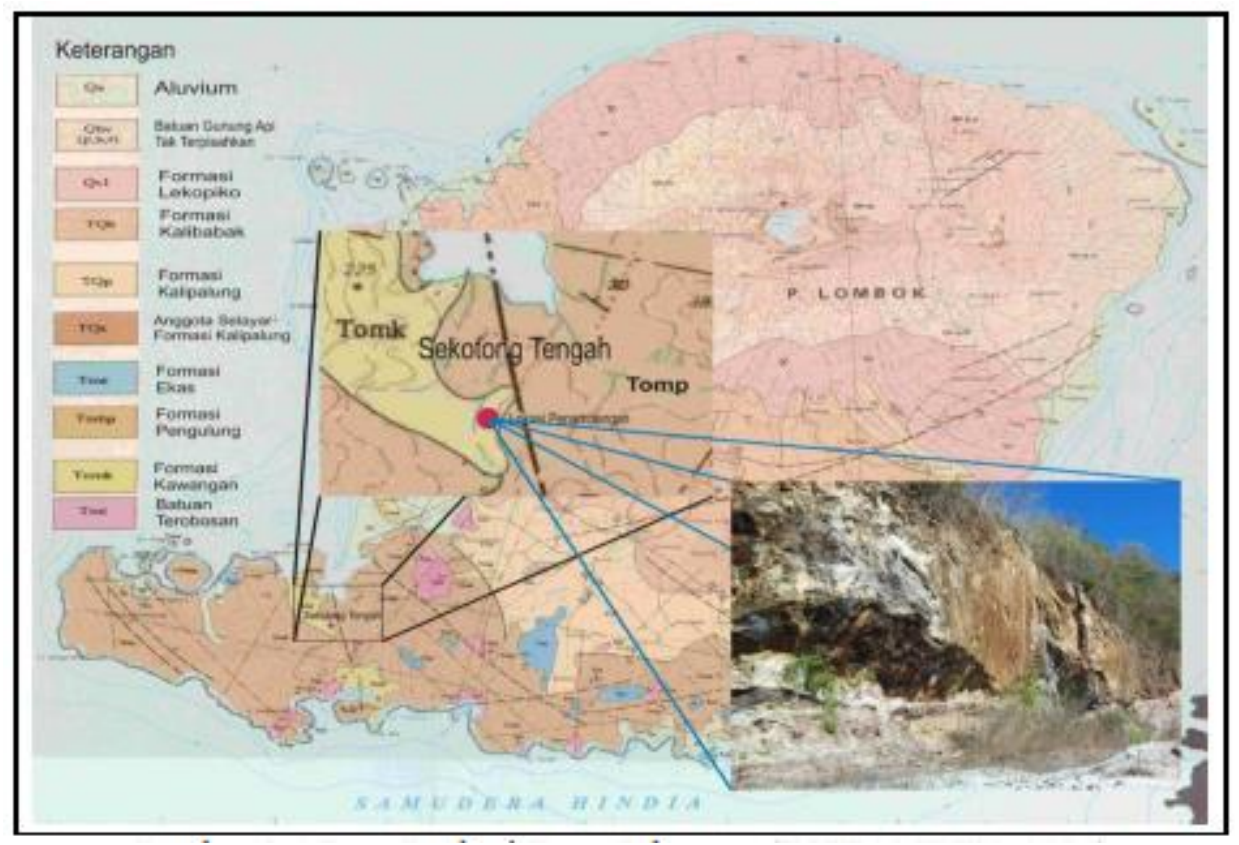

Figure 6 Geological Map of Sekotong Village (DISTAMBEN, 1994)

Based on the geological map of the Sekotong area as shown in Figure 6, the area is generally composed of several rock formations as follows:

- Rock units from the Penggulung Formation

The Pengulung Formation consists of units volcanic breccia, andesite tuffs, dacite pyroclastic and andesite lava containing sulfide ore as well as quartz veins. The age of this formation is estimated to be Late Oligocene until Early Miocene. Unit of rock from this formation is including most of the area of research.

- Rock units from the Kalipalung Formation

Kalipalung Formation consists of fluctuation breccia, tufa andesit and lava. Its age is estimated to be Pliocene found in the northern area only covers a small area research. 


\section{METHOD}

Alur penelitian sebaiknya disajikan di bagian ini dilengkapi dengan keterangan gambar. Field data acquisition is carried out in Empol sub-village, Central Sekotong Village, Sekotong sub-district, West Lombok Regency. The Research Area is located at the position of $08^{\circ} 46^{\prime} 44.85^{\prime \prime S}$ and $116^{\circ} 02^{\prime} 52.97^{\prime \prime} \mathrm{E}$ to $08^{\circ} 47^{\prime} 02.20^{\prime \prime} \mathrm{S}$ and $116^{\circ} 03^{\prime} 13.12^{\prime \prime} \mathrm{E}$, with topographic conditions are flat and hilly ones wavy as shown in Figure 7.

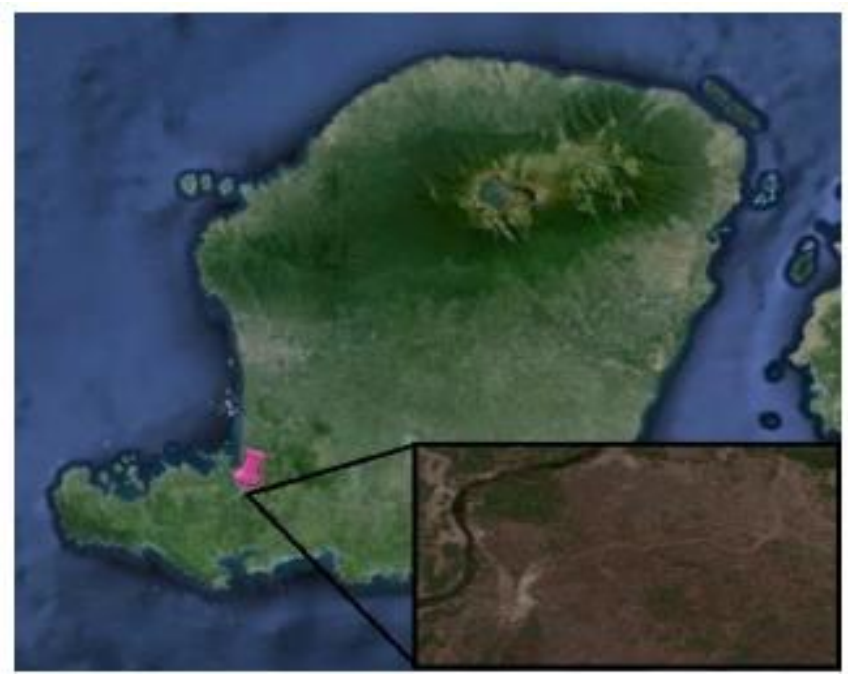

Figure 7 Location of the Study Area

The equipment used in this study are soil box resistivitymeter, a set of G-Sound GL-4100 resistivitymeter, GPS, and a computer with Res2Dinv 3.5, Surfer 10, and Rockwork 15 software.

The stage of this study shown in Figure 8

\begin{tabular}{|c|c|}
\hline \multicolumn{2}{|c|}{$\begin{array}{l}\text { Preliminary study } \\
\text { literature review, field review, and field measurement design }\end{array}$} \\
\hline \multicolumn{2}{|r|}{$\Longrightarrow \quad$ L } \\
\hline \multirow{2}{*}{\multicolumn{2}{|c|}{ pyrrolusite rock sample collection and measurement of 2D resistivity in the Wenner }} \\
\hline & \\
\hline \multicolumn{2}{|c|}{$\begin{array}{l}\text { Data processing } \\
\text { Measurement of sample resistivity and } 2 \mathrm{D} \text { resistivity modeling. The results of the } 2 \mathrm{D} \text { modeling } \\
\text { are then visualized in 3D. }\end{array}$} \\
\hline \multicolumn{2}{|c|}{$\mathrm{P} \quad \mathrm{L}$} \\
\hline \multirow{2}{*}{\multicolumn{2}{|c|}{$\begin{array}{c}\text { Data interpretation } \\
\text { calculation of rock resistivity variations and Mn volume calculation based on 3D visualization }\end{array}$}} \\
\hline & \\
\hline & Conclusion \\
\hline
\end{tabular}

Figure 8 Stage of the study 


\section{RESULT AND DISCUSSION}

Based on the test of resistivity in rock samples that have been conducted at the University Physics Laboratory Mataram, the resistivity value is obtained for Mn carrier rocks amounted to $0.023 \Omega \mathrm{m}$ up to $9.800 \Omega \mathrm{m}$. The resistivity value is obtained from testing of sample almost the same as the theoretical resistivity $\mathrm{Mn}$ carrier rocks as in table 1 . The laboratory test results value then used as a reference for interpret the $\mathrm{Mn}$ carrier rock on cross section of 2D results.

To find out the distribution of Mn mineral carrier rocks is done by inverse modeling geoelectric data by using Res2Dinv software. The results of modeling one of the geoelectric survey line are shown in Figure 9.

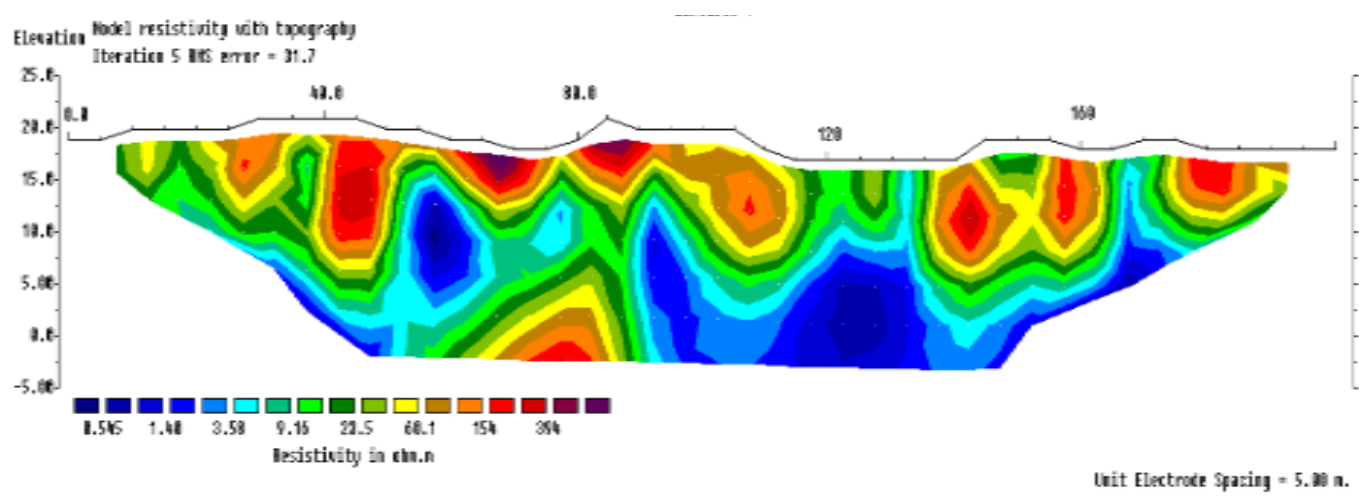

Figure 9 Cross section results of 2D modeling of the first in Empol sub-village, Central Sekotong

Results of inversion of data processing on the first line, the lower resistivity value is obtained the actual surface that ranges between $0.545 \Omega \mathrm{m}$ and $394 \Omega \mathrm{m}$ and depths reaching 22.5 meters. From cross section 2D above, it appears there some dark blue lumps of rock - light blue which is indicated as rock pyrrolusite covered in tuff rock with resistivity values ranging from $0.545 \Omega \mathrm{m}$ to with 3.58 $\Omega \mathrm{m}$. The second line is obtained by value actual resistivity ranges from $0.413 \Omega \mathrm{m}$ up to $1101 \Omega \mathrm{m}$ in depth reach 45 meters, while for the third line values of resistivity obtained ranged between $0.788 \Omega \mathrm{m}$ to $3076 \Omega \mathrm{m}$ with the depth reaches 32.5 meters, whereas in the fourth path the resistivity value is obtained ranges from $1.03 \Omega \mathrm{m}$ to $118 \Omega \mathrm{m}$ with a depth of about 27.5 meters and on the track the latter obtained resistivity values ranging between $0.0294 \Omega \mathrm{m}$ to $420 \Omega \mathrm{m}$ with a depth of about 25 meters.

Based on data from measurements that have been correlated with geological maps, in general the study area is an area formed by volcanic results which are generally the oldest tertiary rocks. The oldest rocks are Tertiary and the youngest are Quaternary dominated by limestone, breccia and tuffs with limestone lenses containing quartz veins as shown in Table 2.

Table 2 Resistivity Values and Lithology Types on first lane in Empol sub-village, Central Sekotong

\begin{tabular}{lcl}
\hline No. & Resistivity & \multicolumn{1}{c}{ Type of lithologi } \\
\hline 1. & $0.545-3.580$ & Pyrrolusite \\
\hline 2. & $9.160-23.500$ & Tuffs \\
\hline 3. & $60.100-154.000$ & Breccia \\
\hline 4. & $154.000-394.000$ & Limestone \\
\hline
\end{tabular}

The results of inversion modeling of all lanes will be used as input in 3D visualization. From this visualization, it can be estimated the amount of deposits from each rock detected by the geoelectric 
method in the area. 3D visualization was carried out using Rocwork 15. Sub-surface rock lithology was obtained based on the range of resistivity values obtained from the measurement results using the resistivity geoelectric method. The lithology is then combined into 3D visualization in solid form. The results of the $3 \mathrm{D}$ cross section visualization are shown in Figure 10

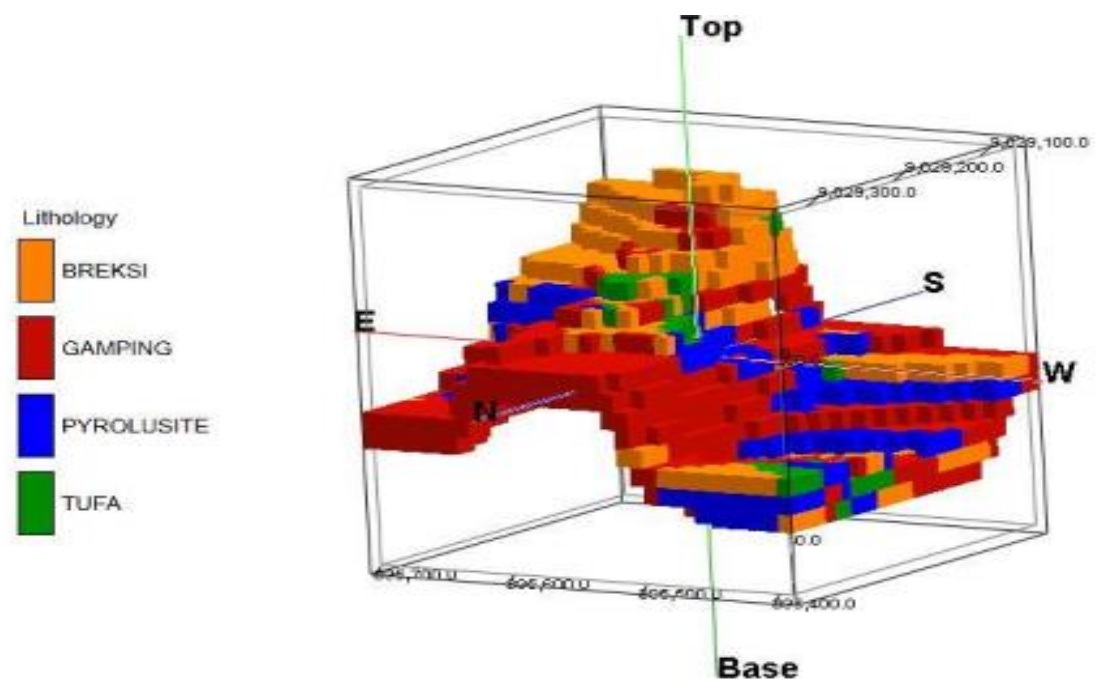

Figure 10 3-D visualizations results of all lanes using software RockWorks 15 in Empol sub-village, Central Sekotong

In the cross section of the results of 3D visualization there are four types of layers of lithology in the study area. The results of the visualization of the layers above show there are four colors. i.e. orange is breccia, green indicates tuffs and red is limestone which appears to dominate the $3 \mathrm{D}$ cross section, this is due to the geological conditions of the study area composed of tertiary rocks, where tertiary rocks consist of limestone and quartz vein. While the blue color is interpreted as pyrroleusite rock $\left(\mathrm{MnO}_{2}\right)$.

Based on the 3D visualization that has been done, pyrroleusite rocks are located in the third layer. There are several chunks of pyrrolusite rock which is almost evenly distributed in the study area. Largest pyrolusite rocks are found in the southwest of the study area as shown in Figure 11.

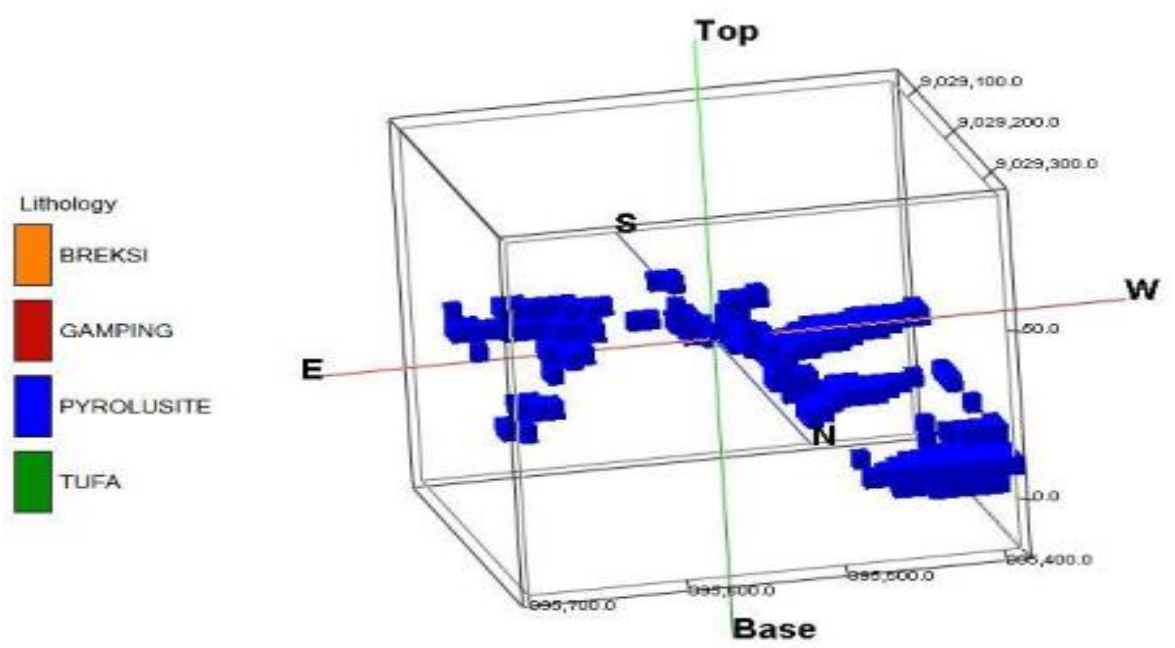

Figure 11 Layer visualization results pyrrolusite rocks on southeast view at Empol sub-village, Central Sekotong 
From the results of volumetric calculations using RockWorks 15 software, it can be seen that the volume of the pyrolusite rock layer is around 1,349,000 cubic feet or around $38,199 \mathrm{~m}^{3}$ over a study area of $160,000 \mathrm{~m}^{2}$ with thickness of $100 \mathrm{~m}$.

\section{CONCLUSSION}

Based on study that has been carried out in Empol Sub village, Central Sekotong Village, Sekotong Sub district, there are deposited of manganese carrier rock (pyrroleusite) about $38,199 \mathrm{~m}^{3}$.

\section{UNKNOLEDGMENT}

Thank you to Agus Wahid Habiburrahman, S.Si. who always accompanied the writer during the acquisition in the field and friends of Aulia, Nopi, Imam who helped during the field and the preparation of the final project and this article.

\section{REFERENCES}

Dinas Pertambangan Dan Energi. 2013. Statistik Dan Energi Sumber Daya Mineral. NTB : Dinas Pertambangan Dan Energi Provinsi NTB.

Distamben. 1994. Info Pertambangan Dan Energi Edisi 01. NTB : Dinas Pertambangan Dan Energi Provinsi NTB.

Gunradi, Rudy. 2005. Evaluasi Sumber Daya/Cadangan Bahan Galian Untuk Pertambngan Skala Kecil Daerah Pulau Lombok Provinsi Nusa Tenggara Barat. Hasil Kegiatan Subdit Konservesi, TA 2005

Karisma. Uci. 2013. Pola Bawah Permukaan Dengan Metode Distribusi Situs Geolistrik Resistivitas Megalitikum Res3D Di Kecamatan Grujugan Kabupaten Bondowoso. Skripsi. Universitas Jernber

Margaworo P, Ayu. 2009. Identifikasi Batuan Dasar Di Desa Kroyo Karangmalang Kabupaten Sragen Menggunakan Metode Gelistrik Dipole-Dipole. Skripsi. Universitas Sebelas Maret.

Pangestu. 2014. Makalah Bijih Besi Mangan dan Gips. Diunduh di http://npangestu.blogspot.co.id/2014/03/. D iakses pada tanggal 15 September 2015.

Reynolds, John,M. 1997. An Introduction to Applied and Enviromental Geophysics. : John Wiley \& Sons ltd. NewYork

Soeharto. R, Simpwee. 2000. Hasil Eksplorasi Mineral Logam di Jalur Busur Magmatik SundaBanda. Jurnal Subdit Eksplorasi Mineral Logam.

Wahyuni, Sri. 2011. Pendugaaan Pencemaran Lindi Dari TPA Kebun Kongok Menggunakan Metode Geolistrik Resistivitas Konfigurasi · wenner.Skripsi. Universitas Mataram.

Wirayuda, Hizbulwathon. 2013. Analisis Deposit Mineral Mangan (Mn) Di Desa Pucung Kecamatan Eromoko Kabupaten Wonogiri. Skripsi.Universitas Negeri Semarang.

Telford, And Sheriff. 1976. Applied Geophysics, USA Cambridge University Press.

Telford, W.M., L.P. Geldart, and R.E. Sheriff. 1990.Applied Geophysics Second Edition, New York: Cambridge University Press 